\title{
Bosnian traveller Mohammad Hancic in Egypt during Ottoman Empire
}

\author{
Ali Akbar Ziaee
}

\begin{abstract}
Some Bosnian Muslims known as Boshniaks travelled to Arabian countries and were affected by Islamic civilization. One of them is Muhammad Hancic, a well-known writer and traveller in Bosnia and Herzegovina during the early 20th century. Muhammad Hancic was born in Sarajevo in 1906. He graduated from primary school and Madrasah in his native town. Following his completion of schooling in 1926, he went to Egypt and enrolled al-Azhar University. He obtained a university degree in 1931. Following his graduation, he performed hajj, and then returned to his homeland.

In 1932, after completing his military service, he found employment at Gazi Khusrow Bey's Madrasah as a lecturer. In 1937 he began work in Gazi Khusrow Bey's library. He established cooperation with a number of magazines and was also a prolific translator. He translated many books from Arabic to Bosnian. He also translated into Arabic many of his own texts written in Bosnian.
\end{abstract}

Key Words: Ottoman Period, Boshniak, Saqalibs, Fatimids.

\section{Boshniaks in Egypt during the Ottoman Age}

The researchers are of the view that the first contacts between Arabs and Slavs occurred in North Africa, primarily Egypt and also through Andalusia. The Slavs figured prominently in the structure of Ottoman authorities and organs of government. It reached such an extent that some authors wrote numerous commendations honouring the Slavs, meaning Saqalibs, which was the name Arabs used when referring to Slavs. To be fair, the Arabs used this term to refer to Slavs, Gauls and Romans - the European peoples mostly. Historical sources dating from the Ottoman Age abound with names of Boshniaks who attained vizierial or some even higher dignitary position, indicating here were many Boshniaks amongst distinguished scholars and learned men.

Čban Mustafa Pasha [1] was one of the first Boshniaks who reached Egypt in 1521, four years following the Ottoman conquest of Egypt. He was a stout-hearted, brave and just man who later became the governor of Rumelia and eventually assumed vizierial position, functioning as muhafiz (i.e., governor) in Egypt and later, being urged by his wife, he returned to Diwan. He died in 1528 and was buried in Gebze, in front of the mosque, his pious endowment.

Muhammad Hancic was born in Sarajevo, in 1906. He graduated from primary school and madrasah in his native town. Following his completion of schooling in madrasah in 1926, he went to Egypt and enrolled alAzhar University. He obtained a university degree in 1931. Following his graduation he performed hajj and then returned to his homeland.

In 1932, after completing military service, he began a career in the fields of culture and education in the most important Boshniak educational and cultural institutions of the period - Gazi Khusrow Bey's Madrasah and Gazi Khusrow Bey's Library and later at the Bey's Madrasah as a lecturer. He also established cooperation with a number of magazines such as al-Hidayah, Novi Behar and the Islamic Community Gazette, and for several years he was an editor for al-Hidayah. He was a prolific translator and translated many books from Arabic to Bosnian. He also translated to Arabic many of his own texts written in Bosnian.

\section{Egypt in Early $20^{\text {th }}$ Century in the Eyes of Bosnian Traveller}

Muhammad Hancic demonstrated a particular affection towards the Islamic world, in other words, Arabic countries. This is borne out by the fact that he transcribed the literary works of Abdurrahim ibn bu Bakr ibn Ibrahim Iraqi, and Mahajjah al-Qurb min Muhabbah al-Arab. He brought this book from Egypt. The book was published in Cairo in 1346, and before that in Bombay in 1303 Hijrah era. The book was logged in the catalogue of Gazi Khusrow Bey's Library under the number R-662. Another book is also logged in this catalogue under the title: Kitab Yasfu fihi Rihlati ila Misr, written by Muhammad Hancic himself. The book has 46 leaves. In this book the author commented on his previously written book: Rihlati ila Misr.

Muhammad Hancic was exceptionally inclined towards the Arabic language. In the preface of his travelogue from Egypt, referring to the Hadith of Prophet Muhammad, Hancic reveals his love for the Arabic language. He wrote: This Hadith was taken over from Hakim's Mustadrak which is daif (week) according to Zahabi, and thus cannot be used as a real evidence of Arabic superiority over other languages [2]. 
It is particularly interesting to establish why Egypt was such a significant theme for this Boshniak travel writer. If we ask the tourists from $21^{\text {st }}$ century why they chose Egypt as a travel destination, they will probably say because of its pyramids, oriental bazaars and abundance of various goods, or something like that. However, Boshniak visitors heading to Egypt in the early $20^{\text {th }}$ century surely were not led by such motives. These folk considered Egypt the country of al-Azhar. In his travelogue, Hancic concludes that God gave each country a particular feature by which it is distinguished from other countries, and thus was Egypt blessed by alAzhar. Therefore, the science devotees from all around the world came there to acquire knowledge.

Muhammad Hancic wrote that on $24^{\text {th }}$ Rabi'u l-awwal 1345, he set off from his native town "Saray Abad" meaning Sarajevo, and took a Greek ship on Saturday, $1^{\text {st }}$ Rabi' ul-Ahir in the same year. On Thursday, he arrived in Alexandria, Egypt. He spent a night there and on the morrow reached Cairo. Referring to the sayings and traditions of the Prophet, and to the biographies of the great scholars and citing the verses of Arabian poets, he demonstrates the importance travel for the acquisition of knowledge. But before he describes Egypt, Muhammad Hancic speaks of his native town Sarajevo first. He quotes Turkish travel writer Evliya Çelebi, who speaks of the mosques, madrasas, people, bridges and the pleasant climate $[3,4]$. In one of his chapters, he mentions his desire to visit Mecca and honoured Medina, while in another chapter he lists the advantages of Egypt. In order to augment these advantages, Muhammad Hancic refers to works such as al-Suyuti's Husn alMuhadhirah; citing: he says that Misr (Egypt) in Qur'an is mentioned 29 times, and according to al-Suyuti - 30 times [5]. Hancic also quotes Hadiths of the Prophet from Muslim's Sahih, some of them passed on by Abu Zar, alluding to the advantages of Egypt. Hancic indicates other traditions from sources such as Muajam al-Kabir by Tabarani and Dalayil al-Nubuwwah by Bayhaqi. According to Hancic, what gives a particular value to Egypt was the presence of God's prophets in this area. One of the chapters in Hancic's book deals with the poetry praising Egypt. He quotes the standpoint of Shahabuddin Nuwayri given in the book Nihayah al-Arab fi Funun al-Adab. According to Nuwayri, the Egyptian ruler is actually lord of the entire world, and Hancic concurs with that, saying that it seems right to him.

A particular detail in this work of Hancic is his criticism of the population of Egypt. Hancic says that Yaqut—in his book Mu'jam al-Buldan — argued that the only flaw of Egypt is the Egyptians. He is surprised by this point of view regarding Egyptians who have been the heirs of such a rich culture.

Hancic dedicated a particular chapter to the Egyptians. He writes that God, when creating the people, created their morals as well. Then wealth said it will reside in Egypt but humiliation also decided to live there. In his interpretation of this tradition, whose origin one does not mention, Hancic states that the humiliation of Egyptians follows their wealth. Namely, that foreign rulers have always tried to conquer Egypt in order to reach her wealth and riches, and that this was also always the aim of Egypt's common citizens. Referring to alMawaiz wa al-'I'tibar bi Dhikr al-Khitat wa al-'Athar (about the planning of Cairo and its monuments) written by al-Maqrizi, Hancic describes Egyptians as impatient and timid people, pessimistic by its nature, malicious and inclined to speak evil of others to the ruler [6]. Thus, he concludes that a lot of evil is in these people. Naturally, he finds few Egyptians to be praiseworthy and moral people, not like others. And furthermore, since this country begets only fear and hopelessness, he states that the lions had never lived in it, for when they came to this country, they would loose vigour and were subdued. He points out the verses of Shaykh Abdullah Sharqawi, the sixth shaykh of al-Azhar, (died in $1171 \mathrm{AH}$ ), in which he also criticises the Egyptians [7].

The editor of this text feels that pinning the label of 'immoral' on an entire people, and proving that by the verses of the poets is an improper and erroneous approach. Moreover, we talk about a great nation that belongs to the ummat of the Prophet of Islam. Although Hancic, refers to certain historical sources and verses of the poets as portraying Egyptians in such a bad manner, one thing is undeniable however: anyone who visits present-day Egypt witnesses the generosity, hospitality, and benign nature of the Egyptian character.

In the next chapter, Hancic writes about the Nile. He submits that if not for the Nile there would not have been life and agriculture in Egypt, and states that some books claim Egypt would be gone if the Nile ran dry. Hancic writes that Englishmen threatened Egypt with blocking the Nile if the Egyptians would oppose Great Britain. In a further text, Hancic describes the Nile as the longest and the most beneficial river in the world. The life of Egypt heavily leaned on the Nile and no wonder ancient Egyptians worshipped her and offered a virgin every year in sacrifice to the river. Only after the second caliph Omer assumed power did this horrible practice cease.

In one of the chapters, Muhammad Hancic deals with the three great pyramids of Giza. He wrote that many smaller pyramids surrounded these pyramids, but that Salahuddin Ayyubi ordered them levelled. Hancic reports that he personally visited the pyramids several times and that each time he felt bad. For him, the pyramids represented worthless and meaningless edifices that so many people invested huge efforts in vain to construct. He reminds himself of Al'Qur'an'sverses which indicate the obedience of people to Pharaoh only increased his arrogance to such an extent that he began to think of himself as God. After this, Hancic refers to the work of Ibn Fadlullah Umari's Masalik al-Absar who alleges that the pyramids remained as a moral 
reminder for men [8]. Following this, he quotes the verses of Ahmad al-Tifashi, al-Zafiral-Haddad al-Iskandari and Abu Salt and Mutanabbi, which describe the Egyptian pyramids.

In the next chapter, Hancic writes about the conquest of Egypt at the time of the second caliph Omer's reign and mentions the conquerors of Egypt -'Amr ibn al-'Aas and Zubair ibn Awwam. In this respect, he offers no more information than the regular historical sources. Thereupon, he mentions Fadlullah Umri's notes on the Mosque of 'Amr ibn al-'Aas in Al-Fustat. Hancic records that in his time no lecturing or scientific activities took place there. Moreover, the Moslem prayers in Moslem congregation were not performed regularly. Only once a year, at jum 'ah prayer, a number of people from all over would gather there, and this occurred on the last Friday in the holy month of Ramadan. During his first year of staying in Egypt, Hancic attended the mentioned jum'ah service and prayer. He chronicles that the high state officials, ministers, religious high dignitaries and many ordinary people attended this service. Hancic also passed on data on this mosque from the work of Ibn Daqmaq and mentions some deviations which he noted amongst the congregation in Mosque of 'Amr ibn al'Aas in al-Fustat, and concludes that these new-fangled things cause damage to Islam.

In the next chapter he deals with the life of 'Amr ibn al-'Aas. One of the chapters is dedicated to the foundation of Cairo; another deals with the Fatimid Dynasty; and in another chapter he speaks of the arrival of Jauhar al-Saqlabi in Egypt and his biography.Hancic says that in some foreign magazines he learned that Jauhar's origin was Saqalib. Therefore, Hancic concludes that he was his fellow-countryman. During the reign of the Fatimids, as Yaqut and Ibn Ayaz report, many Saqalibs had been visiting Egypt. Some of them assumed high positions in the military, administration and government.

Muhammad Hancic dedicated a separate chapter to al-Azhar and its history. He writes that al-Azhar is the true and only reason he came to Egypt, and if asked what al-Azharis, he would give a following answer: alAzhar is the first mosque built in Egypt, the oldest centre of dissemination of Islamic science and knowledge, the garden of trees - one next to another - which endowed Muslims with numerous great scholars, and until his day had remained a Centre for knowledge seekers, intellectual sciences, and the passing on of traditions. According to Hancic, Jauhar the Sicilian, established al-Azhar on Saturday, the $24^{\text {th }}$ of Jumada-ul-Awwal, 359 AH. Their constructions took thirty months and were completed on the $23^{\text {rd }}$ of Ramadan, $361 \mathrm{AH}$. The University was named al-Azhar in honour of late Sayyed al-Fatimah al- Zahra, from whom, as it is believed, the Fatimids descend. Hancic writes that additional construction has been carried out at al-Azhar for centuries, and that its annexing and enlargement were ongoing. After writing the chapter on al-Azhar, Hancic decided to abandon any further description of Egypt and concludes his book with the following words: "This is a note dedicated to Allah the Merciful (al-Rahim), from the poor Muhammad Hancic; this work is not complete but it ends here.

\section{Sources:}

[1] Shahin, Kaya, Empire and Power in the Reign of Suleyman, Cambridge University Press, 2013, p.54

[2] Al-Hakim, Abu Abdullah. "Al-Mustadrak-ala-Sahihain." 1st. Byrut: Dar al-Kutub al'Ilmiah. Part 4 (1990).

[3] Çelebi, Evliya, Seyit Ali Kahraman, and Yücel Dağlı. Günümüz Türkçesiyle Evliya Çelebi Seyahatnâmesi: Bursa-Bolu-TrabsonErzurum-Azerbaycan-Kafkasya-Kırım-Giritz. Vol. 2. Yapı Kredi Yayınları, 2004.

[4] Çelebi, Evliya, Seyit Ali Kahraman, and Yücel Dağlı. Günümüz Türkçesiyle Evliya Çelebi Seyahatnâmesi: Bursa-Bolu-TrabsonErzurum-Azerbaycan-Kafkasya-Kırım-Giritz. Vol. 2. Yapı Kredi Yayınları, 2004.

[5] Suyuti, Jalal al-Din“Abd al. "Rahman, Husn al-Muhadarah fi Tarikh Misr wa 'lQahirah, 2 vols, ed." M. Abul al-Fadl Ibrahim, Dar Ihya al-Kutub al-Arabiyah, Cairo (1968).

[6] Al-Maqrizi, Taqi al-Din Ahmad. "b., 'Ali b. ." Abd al-Qadir, al-Mawa'izwa al-I’tibar fi Dhikr al-Khitatwa al-Athar, ed. by Ayman Fu'ad Sayyid, (London: Mu'assasat al-Furqan lil Turath al-Islami, 1995) (1957).

[7] Geran, Peter, Islamic Roots of Capitalism: Egypt 1760-1840, New York: Syracuse University Press, 1998 , p. 45.

[8] al-Umri, Shihabuddin. "Masalik-ul-Absar fi Mumalik ul-Amsar (written in middle of 14th cent. CE), trs." HI; Hindi trs. in Rizvi. 